\section{Alkalinity Showed Limited Effect on Turfgrass Germination under Low to Moderate Salinity}

\author{
Qi Zhang ${ }^{1}$ and Kevin Rue \\ Department of Plant Sciences, North Dakota State University, Department \\ 7670, P.O. Box 6050, Fargo, ND 58108
}

Additional index words. daily germination rate, final germination percentage, $\mathrm{pH}$

\begin{abstract}
Saline and alkaline conditions often coexist in nature. Unlike salinity that causes osmotic and ionic stresses, alkalinity reflects the impact of high $\mathrm{pH}$ on plant growth and development. In this research, seven turfgrass species, tall fescue (Festuca arundinacea Schreb.), kentucky bluegrass (Poa pratensis L.), creeping bentgrass (Agrostis stolonifera L.), perennial ryegrass (Lolium perenne L.), zoysiagrass (Zoysia japonica Steud.), bermudagrass [Cynodon dactylon var. dactylon (L.) Pers.], and alkaligrass [Puccinellia distans (Jacq.) Parl.], were germinated under 10 saline-alkaline conditions [two salinity concentrations $(25$ and $50 \mathrm{~mm}) \times$ five alkalinity levels $(\mathrm{pH}=7.2,8.4,9.1,10.0,10.8)]$ in a controlled environment. Seed germination was evaluated based on final germination percentage and daily germination rate. Alkaligrass and kentucky bluegrass showed the highest and lowest germination under saline conditions, respectively. Limited variations in germination were observed in other species, except bermudagrass, which showed a low germination rate at $50 \mathrm{~mm}$ salinity. Alkalinity did not cause a significant effect on seed germination of tested turfgrass species.
\end{abstract}

High soil salinity is often problematic to turfgrass managers. Salinity causes osmotic stress (i.e., physiological drought), ion imbalance, and phytotoxicity and adversely affects plant growth and development (Qian and Harivandi, 2007), resulting in reduced visual quality and playability of the turfgrass. Many factors such as deficient precipitation, water percolation from high water tables, low-quality water (e.g., recycled water, well water, and salt water from sea water intrusion), and salts from fertilizers and deicer can result in high soil salinity $(\mathrm{Wu}$ and Lin, 1993). Various turfgrass species respond to soil salinity differently. For example, kentucky bluegrass is very sensitive to saline conditions, whereas creeping bentgrass shows moderate salinity sensitivity (Marcum, 2007). Tall fescue, perennial ryegrass, and zoysiagrass are moderately tolerant to salinity, whereas bermudagrass and alkaligrass are highly tolerant (Marcum, 2007).

Alkalinity (high $\mathrm{pH}$ ) and salinity often coexist in nature, especially in sodic soils because of the hydrolysis of exchangeable sodium (Guerrero-Alves et al., 2002; Javid et al., 2011). Of the cultivated land worldwide $\left(13.2 \times 10^{9} \mathrm{ha}\right), \approx 23 \%$ is affected by salinity and another $37 \%$ is affected by sodicity (Läuchli and Lüttge, 2002). More

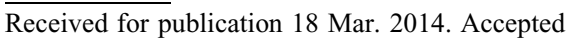
for publication 8 July 2014.

This project was supported in part by Hatch project ND01540.

We thank Drs. Alan Zuk and Esther McGinnis for their valuable suggestions and comments during the preparation of this manuscript.

${ }^{1}$ To whom reprint requests should be addressed; e-mail qi.zhang.1@ndsu.edu.
}

than $70 \%$ land in northeast China is covered by alkaline meadow and it is expanding (Kawanabe and Zhu, 1991). High soil pH (greater than 8.5) has been reported on more than $80 \%$ of the sodic soils in Australia (Rengasamy, 2002). Qian and Mecham (2005) reported that an increase of soil salinity, sodium content, and $\mathrm{pH}$ on golf fairways was observed after long-term (4 to 33 years) use of recycled water.

Previous research on salinity stress has been focused on the impact of neutral salts such as $\mathrm{NaCl}$ on plant growth and development (Dai et al., 2009; Zhang et al., 2011). Recent studies have demonstrated that the combined saline-alkaline conditions are more detrimental to plants than salinity alone (Javid et al., 2012; Li et al., 2010; Liu and Shi, 2010; Paz et al., 2012; Shi and Wang, 2005). Lower seed germination was observed in sheepgrass [Leymus chinensis (Trin.) Tzvel.], switchgrass (Panicum virgatum L.), and wheat (Triticum aestivum L.) under the combined saline-alkaline stress than salinity alone (Guo et al., 2010; Lin et al., 2014; Liu et al., 2014). Many seeds exposed to the combined saline-alkaline condition were not able to recover even after the stress was removed, suggesting that high $\mathrm{pH}$ may cause structural decomposition in seeds (Guo et al., 2010). Photosynthetic pigments, stomatal conductance, and net photosynthetic rates were significantly reduced in sunflower (Helianthus annuus L.) under saline-alkaline conditions, but not saline stress alone (Liu and Shi, 2010). In addition to the salinity injuries, alkalinity under saline-alkaline conditions may inhibit iron absorption and cause precipitation of calcium, magnesium, and phosphorus, thus interrupting ion homeostasis in plant cells
(Javid et al., 2012). A higher $\mathrm{Na}^{+} / \mathrm{K}^{+}$ratio was observed in various crops under the combined stress than salinity stress alone (Javid et al., 2012; Liu and Shi, 2010; Shi and Wang, 2005). Li et al. (2010) and Liu and Shi (2010) reported higher total organic acid production in plants under the combined salinealkaline stress than the saline condition alone. Accumulation of organic acid contributes to osmotic adjustment under a stressful environment; however, it is energy-consuming resulting in reduced ability of ion regulation (Li et al., 2010; Liu and Shi, 2010). Furthermore, alkaline conditions may interfere with abscisic acid distribution between roots and the rhizosphere and its transportation within plant organs, resulting in root growth inhibition (Degenhardt et al., 2000; Javid et al., 2011).

To our knowledge, turfgrass responses to saline-alkaline conditions have not been evaluated. Therefore, this study was conducted to determine the effect of a saline-alkaline condition on turfgrass during seed germination, a critical period of turfgrass development and when plants are most likely to experience salt accumulation (Almansouri et al., 2001). Results will provide useful information to managers for selecting turfgrass species tolerant to saline-alkaline soil conditions and to breeders for screening and developing tolerant germplasms.

\section{Materials and Methods}

Seven turfgrass species were used in this experiment, including four commercially available cool-season turfgrasses ('L-93' creeping bentgrass, 'Stonewall' tall fescue, 'Diva' kentucky bluegrass, and 'Zoom' perennial ryegrass), one native cool-season grass ('Salty' alkaligrass), and two warm-season turfgrasses ('Zenith' zoysiagrass and 'Riviera' bermudagrass). These six commercial species are commonly used on golf courses, recreational areas, and residential home lawns, whereas the native species have shown good tolerance to both saline and alkaline conditions (Marcum, 2007; Turgeon, 1991) and high potential for turfgrass use under low maintenance (McKernan et al., 2001; Watkins et al., 2011).

Saline-alkaline conditions were stimulated using neutral $\left(\mathrm{NaCl}\right.$ and $\left.\mathrm{Na}_{2} \mathrm{SO}_{4}\right)$ and alkaline $\left(\mathrm{Na}_{2} \mathrm{CO}_{3}\right.$ and $\left.\mathrm{NaHCO}_{3}\right)$ salts following the method of Li et al. (2009). A total of 11 treatments were included: one control [deionized/distilled water $\left(\mathrm{ddH}_{2} \mathrm{O}\right)$, electrical conductivity $(\mathrm{EC})=0.1 \mathrm{dS} \cdot \mathrm{m}^{-1}, \mathrm{pH}=7.1$ ] and a two (salinity level at 25 and $50 \mathrm{~mm}$ ) $\times$ five ( $\mathrm{pH}$ level at 7.2, 8.4, 9.1, 10.0, and 10.8) factorial combination.

The seeds of each grass species were surface sterilized and germinated following the method of Zhang et al. (2011) with minor modifications. The seeds were submerged in $70 \%$ ethanol for $5 \mathrm{~min}$ followed by $2 \%(\mathrm{v} / \mathrm{v})$ sodium hypochlorite solution for $20 \mathrm{~min}$ and then rinsed three times with $\mathrm{ddH}_{2} \mathrm{O}$. Forty surface-sterilized seeds of each grass species were placed on seed germination paper (Anchor Paper Company, St. Paul, MN) in 
$100 \times 15-\mathrm{mm}$ petri dishes. Before seed plating, the germination paper was moistened with $10 \mathrm{~mL}$ of $\mathrm{ddH}_{2} \mathrm{O}$ or salt solutions. Petri dishes were sealed with parafilm and placed in a culture room at $25 \pm 2{ }^{\circ} \mathrm{C}$ under fluorescent light $\left(36 \mu \mathrm{mol} \cdot \mathrm{s}^{-1} \cdot \mathrm{m}^{-2}\right)$ with a 16 -h photoperiod.

The number of germinated seeds per dish was counted three times a week for 4 weeks. A seed was considered to be germinated when its emerged shoot was visible. Final germination percentage (FGP) and daily germination rate (DGR) were calculated following the method of Zhang et al. (2011) in which FGP $(\%)=100 \times[(\Sigma n) / 40]$ and DGR $(\% / d)=100 \times$ $[\Sigma(n / D)] / 40$, respectively, where $n$ was the number of new seeds germinated at each counting and $D$ was the number of days accumulated up to that counting. To provide an accurate indication of stress tolerance, data under saline-alkaline conditions were standardized as the percent germination of the control (Teolis et al., 2009). The increase in the ratio of stress to control was equated as an increase in tolerance.

The experiment was conducted as a seven (grass species) $\times$ two (salinity concentrations) $\times$ five (alkalinity levels) factorial design arranged in a randomized complete block design with three replicates (petri dishes). All data were subjected to analysis of generalized linear model (SAS Institute Inc., Cary, NC). Means were separated with Fisher's protected least significant differences at $P \leq 0.05$. The experiment was conducted twice (Study I and II). The two studies were homogeneous; therefore, data from Studies I and II were pooled for further analysis (data not shown).

\section{Results and Discussion}

Salinity effects on turfgrass germination. An interaction between grass species and salinity level was detected in both FGP and DGR (Table 1). Alkaligrass showed the highest FGP, whereas kentucky bluegrass had the lowest FGP at $25 \mathrm{~mm}$ (Fig. 1). Zoysiagrass had a similar level of FGP as bermudagrass but was significantly higher than tall fescue, creeping bentgrass, and perennial ryegrass (average $=94.1 \%$ of the control). Similarly, alkaligrass and kentucky bluegrass were the most tolerant and the most sensitive to salinity, respectively at $50 \mathrm{~mm}$. No significant difference in FGP was observed among zoysiagrass, tall fescue, creeping bentgrass, and perennial ryegrass at $50 \mathrm{~mm}$ (average $=$
$83.7 \%$ of the control); however, bermudagrass had the second lowest FGP at this salinity level.

A similar trend was observed in DGR (Fig. 2). Alkaligrass and kentucky bluegrass had the highest and lowest DGR, respectively, under saline conditions. Bermudagrass had a similar level of DGR as zoysiagrass, tall fescue, creeping bentgrass, and perennial ryegrass at $25 \mathrm{~mm}$; however, it had the second lowest DGR at $50 \mathrm{~mm}$, which is similar to that of FGP.

This study clearly showed that alkaligrass is the most salinity-tolerant species of the five cool-season grasses tested followed by perennial ryegrass, tall fescue, and creeping bentgrass, whereas kentucky bluegrass is the most salinity-sensitive (Figs. 1 and 2). The results are consistent with previous findings (Dai et al., 2009; Zhang et al., 2011). Zoysiagrass had a similar level of FGP and DGR to tall fescue, perennial

Table 1. Proportion of sum of squares to total sum of squares for final germination percentage and daily germination rate of seven turfgrass species under combined saline-alkaline conditions.

\begin{tabular}{|c|c|c|c|}
\hline Source & df & $\begin{array}{l}\text { Final germination } \\
\text { percentage }\end{array}$ & $\begin{array}{c}\text { Daily germination } \\
\text { rate }\end{array}$ \\
\hline Grass & 6 & $21.7 * * * \mathrm{z}$ & $21.3 * * *$ \\
\hline Salinity & 1 & $7.4 * * *$ & $10.6 * * *$ \\
\hline Alkalinity & 4 & $0.9 \mathrm{NS}^{\mathrm{y}}$ & $0.9 \mathrm{NS}$ \\
\hline Grass $\times$ salinity & 6 & $3.5 * * *$ & $2.8 * * *$ \\
\hline Grass $\times$ alkalinity & 24 & $1.5 \mathrm{NS}$ & $1.5 \mathrm{NS}$ \\
\hline Salinity $\times$ alkalinity & 4 & $0.4 \mathrm{NS}$ & $0.1 \mathrm{NS}$ \\
\hline Grass $\times$ salinity $\times$ alkalinity & 24 & $2.9 \mathrm{NS}$ & $3.0 \mathrm{NS}$ \\
\hline
\end{tabular}

z***A significant difference at $P<0.001$.

${ }^{\mathrm{y}} \mathrm{NS}$ Nonsignificant differences at $P \leq 0.05$.

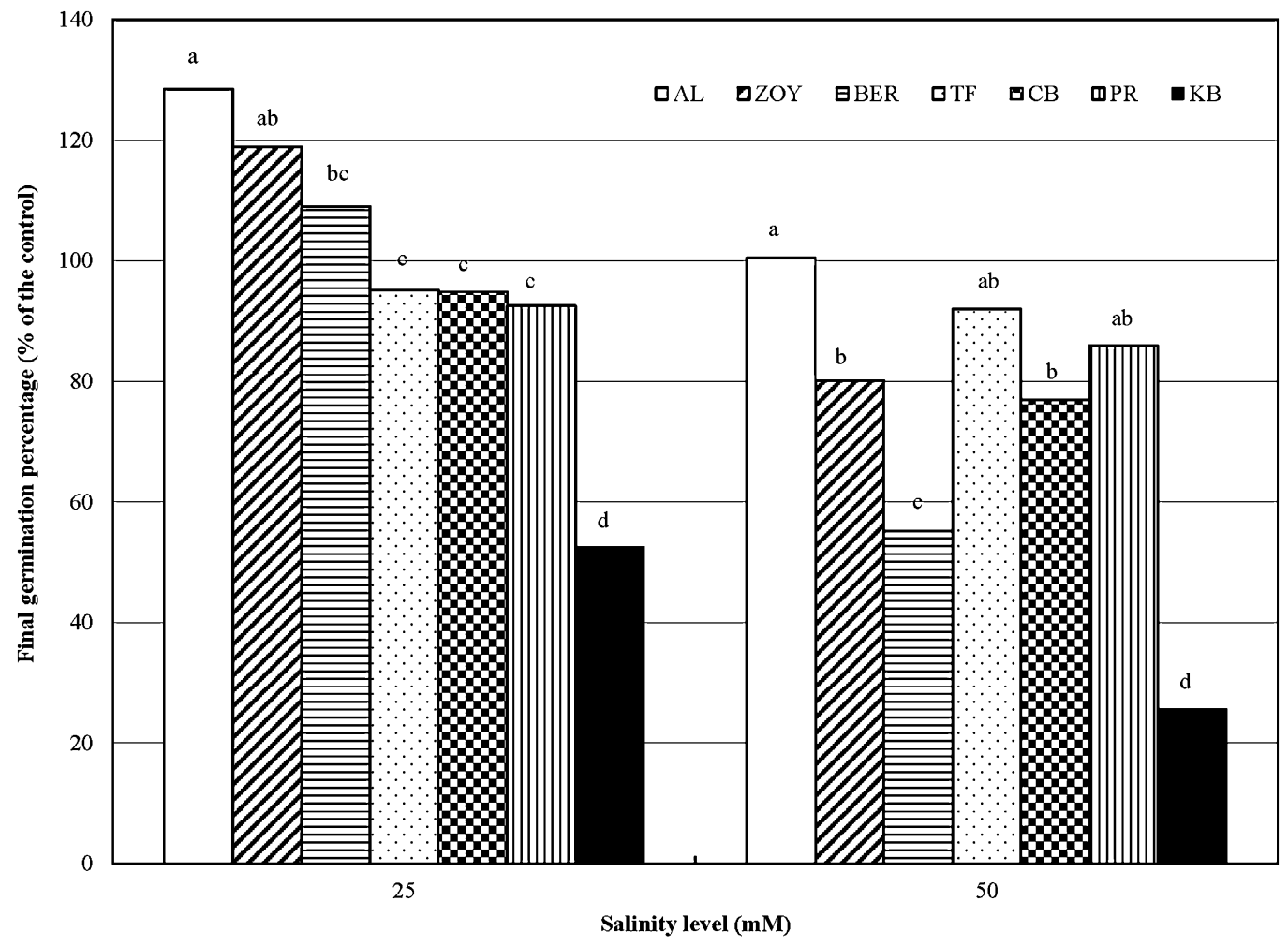

Fig. 1. Final germination percentage of alkaligrass (AL), tall fescue (TF), perennial ryegrass (PR), creeping bentgrass (CB), kentucky bluegrass (KB), zoysiagrass (ZOY), and bermudagrass (BER) as affected by salinity. Data were expressed as percentage of the control (germination under deionized/distilled water) within each species. Means at each salinity level followed by the same letter were not significantly different at $P \leq 0.05$. 


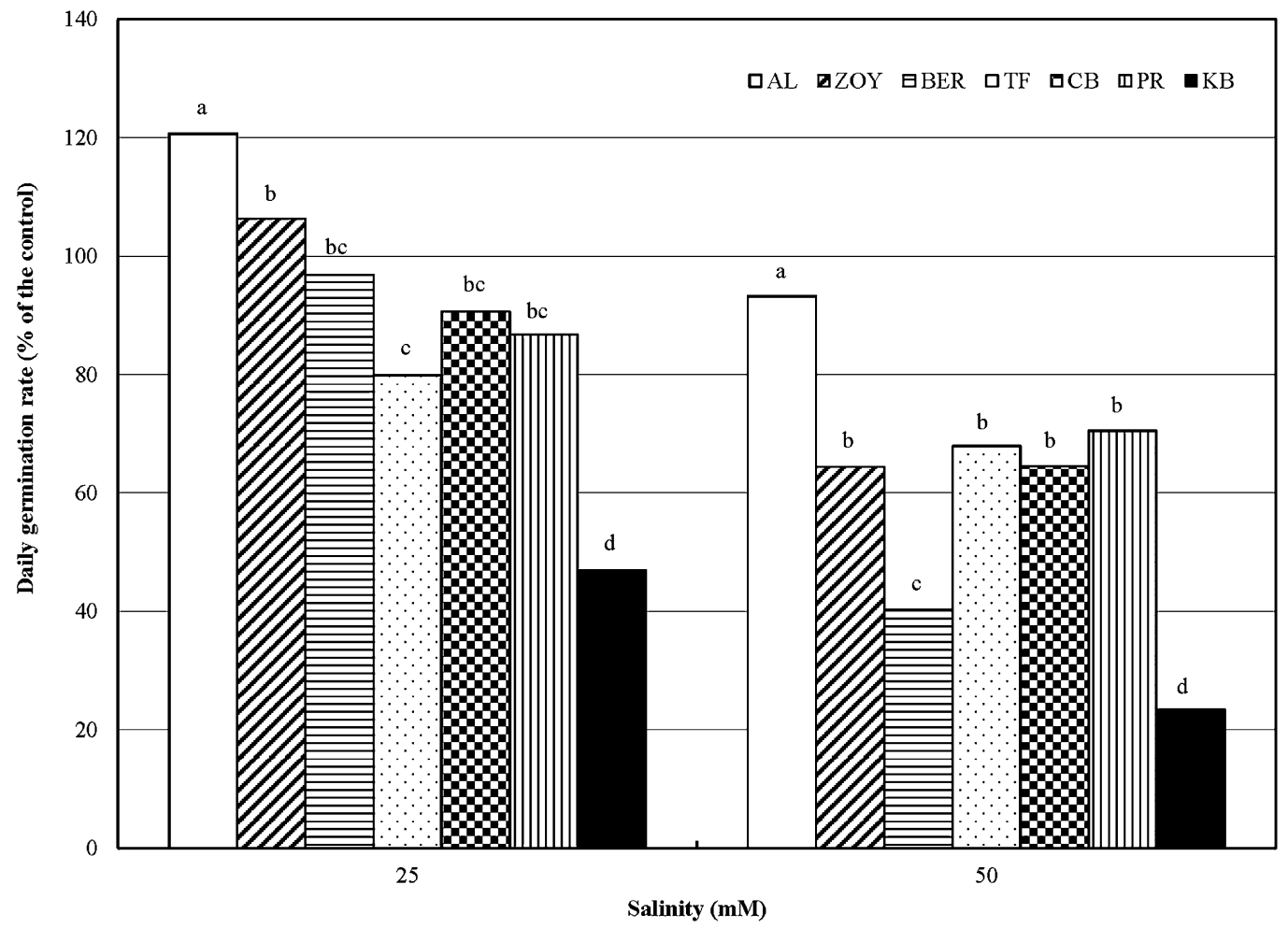

Fig. 2. Daily germination rate of alkaligrass (AL), tall fescue (TF), perennial ryegrass (PR), creeping bentgrass (CB), kentucky bluegrass (KB), zoysiagrass (ZOY), and bermudagrass (BER) as affected by salinity. Data were expressed as percentage of the control (germination under deionized/distilled water) within each species. Means at each salinity level followed by the same letter were not significantly different at $P \leq 0.05$.

ryegrass, and creeping bentgrass at both 25 and $50 \mathrm{~mm}$ in the present study (Figs. 1 and 2). In contrast, bermudagrass performed similarly to the aforementioned cool-season grasses only under low saline conditions $(25$ $\mathrm{mm})$. As the salinity level reached $50 \mathrm{~mm}$, bermudagrass had the second lowest FGP and DGR of the seven grasses evaluated (Figs. 1 and 2). Johnson et al. (2007) reported a similar germination of bermudagrass and zoysiagrass seeds under low salinity ( $3 \mathrm{dS} \cdot \mathrm{m}^{-1}$ or less), consistent with findings of this study. In another experiment, however, seed germination rate of bermudagrass was significantly higher than kentucky bluegrass, tall fescue, and seashore paspalum (Paspalum vaginatum Swartz) under saline conditions $(\mathrm{EC}=0.6$ to $22.5 \mathrm{dS} \cdot \mathrm{m}^{-1}$ ) (Serena et al., 2012). Inconsistent findings of the current research and other studies may be the result of different cultivars used. Salinity tolerance may vary largely within a species (Marcum, 2007; Zhang et al., 2011, 2013). More research needs to be conducted to evaluate intraspecific differences of salinity tolerance in warm-season turfgrass species during germination and the seedling growth stage.

Alkalinity $(p H)$ effects on turfgrass germination. Alkalinity did not influence FGP or DGR in the present study (Table 1). Our results indicate that salinity plays a more important role than alkalinity under the combined stress because salinity and alkalinity accounted for $\approx 10 \%$ and $1 \%$ of variation in seed germination, respectively (Table 1). Research on the effects of saline-alkaline stress on Aneurolepidium Chinese (Trin.)
Kitag., Spartina alterniflora L., and switchgrass (Panicum virgatum L.) shows a similar finding that salinity is the dominant factor under saline-alkaline stress ( $\mathrm{Li}$ et al., 2010; Liu et al., 2014; Shi and Wang, 2005). Severe damage caused by the combined saline-alkaline stress has been reported in other research ( $\mathrm{Li}$ et al., 2010; Liu et al., 2014; Shi and Wang, 2005); however, it was not observed in the present study. It was most likely the result of the higher salinity levels applied in the other studies (ranged from 60 to $600 \mathrm{~mm}$ ) compared with our research (25 and $50 \mathrm{~mm})$. Li et al. (2009) and Shi and Wang (2005) suggested that the effect of alkalinity was more pronounced under high salinity levels. Javid et al. (2012) reported that the salinity-sensitive Brassica juncea L. cultivar had lower plant biomass and tissue potassium, phosphorus, and iron content but higher sodium level than salinity-tolerant cultivars under saline-alkaline stress. In the present study, turfgrass species contributed to more than $20 \%$ of the variation in seed germination (Table 1). Although no turfgrass $\times$ alkalinity interaction was observed, kentucky bluegrass, the most salinity-sensitive grass of the seven species tested in the present study, had decreased germination with an increase of alkalinity; no such trend was observed in the other grasses that have moderate or high salinity tolerance (data not shown). It suggests that salinity level needs to be adjusted according to the salinity tolerance of different plant materials used when the effects of alkalinity and saline-alkaline conditions in future research are explored.

\section{Literature Cited}

Almansouri, M., J.M. Kinet, and S. Lutts. 2001. Effect of salt and osmotic stresses on germination in durum wheat (Triticum durum Desf.). Plant Soil 231:243-254.

Dai, J., D.R. Huff, and M.J. Schlossberg. 2009. Salinity effects on seed germination and vegetative growth of green-type Poа аппиа relative to other cool-season turfgrass species. Crop Sci. 49:696-703.

Degenhardt, B., H. Gimmler, E. Hose, and W. Hartung. 2000. Effect of alkaline and saline substrates on ABA contents, distribution and transport in plant roots. Plant Soil 225:83-94.

Guerrero-Alves, J., I. Pla-Sentís, and R. Camacho. 2002. A model to explain high values of $\mathrm{pH}$ in an alkali sodic soil. Sci. Agr. 59:763-770.

Guo, R., L. Shi, X. Ding, Y. Hu, S. Tian, D. Yan, S. Shao, Y. Gao, R. Liu, and Y. Yang. 2010. Effects of saline and alkaline stress on germination, seedling growth, and ion balance in wheat. Agron. J. 102:1252-1260.

Javid, M., R. Ford, and M.E. Nicolas. 2012 Tolerance responses of Brassica juncea to salinity, alkalinity, and alkaline salinity. Funct. Plant Biol. 39:699-707.

Javid, M., M. Nicolas, and R. Ford. 2011. Current knowledge in physiological and genetic mechanisms underpinning tolerances to alkaline and saline subsoil constraints of broad acre cropping in dryland regions, p. 193-214. In: Shanker, A. and B. Venkateswarlu (eds.). Abiotic stress in plants-Mechanisms and adaptations. 2 Feb. 2014. <http://www.intechopen.com/books/abioticstress-in-plants-mechanisms-and-adaptations/ current-knowledge-in-physiological-and-geneticmechanisms-underpinning-tolerances-to-alkalineand-sa>.

Johnson, C.J., B. Leinauer, A.L. Ulery, D.E. Karcher, and R.M. Goss. 2007. Moderate 
salinity does not affect germination of several cool- and warm-season turfgrasses. Online. Appl. Turfgrass Sci. doi: 10.1094/ATS-20070912-01-RS.

Kawanabe, S. and T.C. Zhu. 1991. Degeneration and conservation of Aneurolepidium chinense grassland in Northern China. J. Jpn. Grassland Sci. 37:91-99.

Läuchli, A. and U. Lüttge. 2002. Salinity in the soil environment, p. 21-23. In: Tanji, K.K. (ed.). Salinity: Environment-plants-molecules. Boston Kluwer Academic Publishers, Boston, MA.

Li, C.Y., B. Fang, C.W. Yang, D.C. Shi, and D.L. Wang. 2009. Effects of various salt-alkaline mixed stresses on the state of mineral elements in nutrient solutions and the growth of alkali resistant halophyte Chloris virgata. J. Plant Nutr. 32:1137-1147.

Li, R., F. Shi, and K. Fukuda. 2010. Interactive effects of various salt and alkali stresses on growth, organic solutes, and cation accumulation in a halophyte Spartina alterniflora (Poaceae). Environ. Exp. Bot. 68:66-74.

Lin, J., Z. Li, S. Shao, Y. Wang, and C. Mu. 2014. Effects of various mixed salt-alkaline stress conditions on seed germination and early seedling growth of Leymus chinensis from Songnen grassland of China. Not. Bot. Horti. Agrobo. 42:154-159.

Liu, J. and D.C. Shi. 2010. Photosynthesis, chlorophyll fluorescence, inorganic ion and organic acid accumulations of sunflower in responses to salt and salt-alkaline mixed stresses. Photosynthetica 48:127-134.

Liu, Y., Q. Wang, Y. Zhang, J. Cui, G. Chen, B. Xie, C. Wu, and H. Liu. 2014. Synergistic and antagonistic effects of salinity and $\mathrm{pH}$ on germination in switchgrass (Panicum virgatum L.). Online. PLoS One. doi: 10.1371/journal. pone.0085282.

Marcum, K.B. 2007. Relative salinity tolerance of turfgrass species and cultivars, p. 389-406. In: Pessarakli, M. (ed.). Handbook of turfgrass management and physiology. CRC Press, Boca Raton, FL.

McKernan, D.K., J.B. Ross, and D.K. Tompkins. 2001. Evaluation of grasses grown under low maintenance conditions. Intl. Turfgrass Soc. Res. J. 9:25-32.

Paz, R.C., R.A. Rocco, H. Reinoso, A.B. Menéndez, F.L. Pieckenstain, and O.A. Ruiz. 2012. Comparative study of alkaline, saline, and mixed saline-alkaline stresses with regard to their effects on growth, nutrient accumulation, and root morphology of Lotus tenuis. J. Plant Growth Regul. 31:448-459.

Qian, Y. and A. Harivandi. 2007. Salinity issues associated with recycled wastewater irrigation of turfgrass landscapes, p. 419-429. In: Pessarakli, M. (ed.). Handbook of turfgrass management and physiology. CRC Press, Boca Raton, FL.

Qian, Y.L. and B. Mecham. 2005. Long-term effects of recycled wastewater irrigation on soil chemical properties on golf course fairways. Agron. J. 97:717-721.
Rengasamy, P. 2002. Transient salinity and subsoil constraints to dryland farming in Australian sodic soils: An overview. Austral. J. Expt. Agr. 42:351-361.

Serena, M., B. Leinauer, R. Sallenave, M. Schiavon, and B. Maier. 2012. Media selection and seed coating influence germination of turfgrasses under salinity. HortScience 47:116-120.

Shi, D. and D. Wang. 2005. Effects of various saltalkaline mixed stresses on Aneurolepidium chinense (Trin.) Kitag. Plant Soil 271:15-26.

Teolis, I., W. Liu, and E.B. Peffley. 2009. Salinity effects on seed germination and plant growth of guar. Crop Sci. 49:637-642.

Turgeon, A.J. 1991. Turfgrass management. 3rd Ed. Prentice Hall Regents, Englewood Cliffs, NJ.

Watkins, E., S. Fei, D. Gardner, J. Stier, S. Bughrara, D. Li, C. Bigelow, L. Schleicher, B. Horgan, and K. Diesburg. 2011. Low-input turfgrass species for the North Central United States. Online. Appl. Turfgrass Sci. doi: 10.1094/ ATS-2011-0126-02-RS.

Wu, L. and H. Lin. 1993. Salt concentration effects on buffalograss germplasm seed germination and seedling establishment. Intl. Turfgrass Soc. Res. J. 7:823-828.

Zhang, Q., S. Wang, and K. Rue. 2011. Salinity tolerance of 12 turfgrasses in three germination media. HortScience 46:651-654.

Zhang, Q., A. Zuk, and K. Rue. 2013. Salinity tolerance of nine fine fescue cultivars compared to other cool-season turfgrasses. Sci. Hort. 159:67-71. 